\title{
Dangerous Safety or Safely Dangerous. Perception of safety and self-awareness in public space
}

\author{
Anna Svensdotter, Mirko Guaralda \\ Queensland University of Technology, Australia \\ School of Design, Creative Industries Faculty \\ a.svensdotter@qut.edu.au | m.guaralda@qut.edu.au
}

\begin{abstract}
Exposure to perceived danger awakens our environmental awareness and sense of individual responsibility. In our rapidly evolving contemporary urban environments, the design of public space is often constrained and focussed on risk mitigation. Designers often rely on the inclusion of mechanisms to control behaviours (eg walls and fences) or rely on displays of authoritarian surveillance (eg CCTV and extensive warning signage). Measures also known as target-hardening (Saraiva \& Pinho, 20II). This can create a reliance on the authoritarian control of urban space, which could result in the disuse of self-regulating mechanisms such as individual responsibility and environmental awareness.

This study investigates perception of danger in public space through a scenario-based investigation focussed on Brisbane, Australia. This study enquires how we sense danger, what provokes our sense of danger and how this affects our environmental awareness. Current exemplary design responses that aim to improve safety in public space are also discussed. The study highlights a need for further research about how authoritatively secured space affects city users, sense of place and community.
\end{abstract}

Keywords: urban environment, placemaking, risk mitigation, urban design

To cite this article:

Svensdotter, A. and Guaralda, M. (2018). Dangerous Safety or Safely Dangerous. Perception of safety and self-awareness in public space. The Journal of Public Space, 3(I), 75-92, DOI:

10.5204/jps.v3il.319

This article has been peer-reviewed and accepted for publication in The Journal of Public Space. Please see the Editorial Policies under the 'About' section of the journal website for further information.

This work is licensed under a Creative Commons Attribution - Non Commercial 4.0 International License https://creativecommons.org/licenses/by-nc/4.0/ 


\section{Introduction}

Feeling exposed, and therefore vulnerable, provokes our sense of danger, awakening environmental awareness and individual responsibility for our own safety (Barnard-Wills, Moore, \& McKim, 2012). This physiological and psychological response to feelings of vulnerability is generally considered a negative state of being, despite the potential heightened self-reliance and protection. However, consideration is warranted for the gentle provocation of such awareness, for long-term solutions of designing safer urban environments (Beck, 1999; Saraiva \& Pinho, 20II).

In today's rapidly evolving urban environments, designers of public spaces are concerned with public liability and focus their design on risk mitigation; this often results in the perceived need of separating competing activities with physical barriers, such as fencing or walls, or excluding undesired uses with inhibitors, like skate deterrents or slats on benches. Displays of authoritarian surveillance, such as CCTV and warning signage is another mechanic used to externalise control in a space and deter undesired activities (Despard, 2012). In some cases, everyday activities are strictly regulated imposing direct control on how a public space is used and perceived (Cox \& Guaralda, 2016). Minimising clash-risk, through isolation and segregation of urban experiences, promote greater reliance by the user of public space on mitigating elements and strategies put in place by the designers, ultimately rendering individual responsibility and environmental awareness redundant (Chitrakar, Baker, \& Guaralda, 20I7; Dangschat, 2009).

These physically movement restrictive, but technologically enhanced public spaces enables our fast paced contemporary lives (Foth, 20I I). How often do we neglect to look as we cross the road, instead trusting the signal of the light apparatus?. How often do we find ourselves lost without our GPS telling us where to turn? Combinations of line markings, curbs, street lights, signage, fenced pedestrian crossings, and median strips keep us at a safe distance from oncoming traffic. Effectively, reliance on mitigating elements creates environments more dangerous than the original threat as nobody is paying attention (Saraiva \& Pinho, 20 I I). For how do we best keep ourselves out of harm's way as contemporary trends of safekeeping in the urban environment limit our experience of engaging with danger?

This paper reports an empirical study that investigates the relationship between perceptions of public spaces and safety within them, with a particular focus on the effect of imposed safety measures on individual responsibility and environmental awareness. It speculates on how an increased sense of danger can improve safety by prompting the individual's self-awareness. It does so by examining what our reaction is to cues of danger in the environment.

\section{Literature review}

Relationships between human-made urban environment and crime have been recognised for over 100 years. Pioneering the concept of Social Criminology Ferri (1896) makes the connection between the criminal and the environment in which the criminal exists. Burgess (1916) and Shaw \& McKay (1942) both connect the development of criminal and delinquent habits and place of residence, describing how age, race, and sex although significant factors contributing to the occurance of juvinile delinquency, the residential ward had a more significant impact. Jeffery (I97I) originated the idea of Crime Prevention Through Environmental Design, considering particular environmental aspects affecting the environmental opportunity. (Burgess, 1916; Ferri, 1896; Jeffery, 1971; Shaw \& McKay, 
1942)One theoretical breakthrough was Jacobs's (196I) criticism of segregatory design policies destroying both established community fabrics and built-in safety structures later referred to as natural surveillability (Wood, Citizens Housing, \& Planning Council, 196I; Wood \& United Nations. Dept. of Economic Social Affairs, 1967). Jacobs's and Woods's critiques were later translated into a rational framework by Jeffery's Crime Preventions Through Environmental Design (CPTED)(I97I). Subsequently, Newman (1972) popularised the concept. While Newman simplified Jeffery's notion concerning duality of physical and psychological reality of offenders, he importantly noted deterioration of safety when residents experienced lack of control over their environment and a resultant diminishing personal responsibility for it. This led Newman to develop Defensible Space Theory, which bases on residents claiming their territory, isolating and 'evicting' criminals from it. Two fundamental notions were pivotal for Newman's version; the defending party must be vigilant and visibly present, and also willing to intervene.

Environmental Criminology was developed mainly by Paul and Patricia Brantingham (I98I) exploring relationships between physical and psychological fear environments. Broken Window Theory developed by Wilson and Kelling (1982) established four elements essential to crime: law, offender, target and place. Environmental Criminology concerns itself with place. Evidence of the fear versus crime relationship emerged in mid-90's via correlation of data from large multi-purpose municipal databases and police information systems (Brantingham \& Brantingham, 1995). Studies of crime versus fear of crime reveal variations relative to eg. gender (Schafer, Huebner, \& Bynum, 2006) and age groups (Fattah, 199I).

Isolated dark or unlit places, with presence of litter or graffiti, exemplify our perception of danger (Brantingham \& Brantingham, 1995), however are not necessarily matched to actual crime levels. Conditions where both fear of crime and actual crime are frequent were recorded in 'edge-locations'; between districts, halfway from major transit locations, border-zones between distinctly differentiating character and social status, along major pathways and at major nodes, where large numbers of movement paths intersect (Brantingham \& Brantingham, 1975, 1981, 1993, 1995; Brantingham, Brantingham, \& Molumby, 1977). Significantly, the research established the fear-crime relationship as variable by feelings of vulnerability (Brantingham \& Brantingham, 1995; Fisher \& Nasar, 1992, 1993). Consequently, managing feelings of vulnerability would appear as significant when managing fear, as would the managing of actual crime.

Jeffery (1990) found that environments do not influence behaviour directly, but rather via human perception. Hence, to attempt creation of safer environments, the internal environment of human users is pivotal (Robinson, 1996). Greater understanding of these relationships emerged through research by Fisher and Nasar (1992, 1993), and Herzog and Chernick (2000) who establish that certain cues in the environment infer dangerous situations. This resulted in detail specific knowledge translatable into physical forms of urban environments. Environmental and spatial cognition and psychological theories, identify environmental cues that provoke fear of crime and describe how these cues generate fear of crime and constrain behaviour (Kitchin, 1994; Pain, 1997). The nature of these cues is both tangible and intangible, varying from specific physical features of built environment to presence of others (Cordner, 1986; Fisher \& Nasar, 1992, 1993; Herzog \& Chernick, 2000; Herzog \& Miller, 1998; Loewen, Steel, \& Suedfeld, I993; Warr, 1990; Winkel, 1986). Research suggests provoking features constitute an assemblage, rather 
than isolated cues, and include physical and psychological environment in combination. By the end of the century, a body of evidence drawn from several academic disciplines supported association between features of the physical environment and fear due to perceived sense of danger (Brownlow, 2005; Fisher \& Nasar, 1992, 1993; Herzog \& Chernick, 2000; Herzog \& Miller, 1998; Merry, 198I; Warr, 1990). Assemblage theory developed from Guattari and Deleuze's A Thousand Plateaus (1980), later furthered by De Landa (20I6), and theorises about the significance of the relationships between elements and features in creating compositions of elements which creates a whole.

Providing a design approach, Crowe et al. (I99I) developed CPTED strategies suggesting three basic classifications; Mechanical, Organisational, and Natural (Sorensen, Hayes, \& Atlas, 2013). These categories relate three reoccurring cues: lighting, greenery, and human presence. Lighting (ability to see and/or be seen) is objective, and hence this cue is often contradicted and contested. Research found street lighting had little effect on crime levels (Atkins, 199I; Ramsay \& Newton, 1991) while Kirk (1988) shows poor lighting in combination with availability of hiding places are perceived as 'bad' places. By mid-2000s, it was concluded that lower lighting levels heighten fear (Stamps, 2005). Claims that increased lighting levels decrease crime levels, however, were contested (Marchant, 2004). Greenery too, has been questioned with arguments around foliage being an element, which counteracts lighting, blocks visual freedom and provides hiding spots for offenders (Fisher \& Nasar, 1992, 1993; Herzog \& Chernick, 2000; Loewen et al., 1993). Kuo, Bacaicoa, and Sullivan (1998), show tree density and grass maintenance strongly affect our sense of safety. Finally human presence has an intriguing dual nature. Congregating crowds induces fear while place activation improves safety. (Skogan, 1990; Warr, 1990). Police visibility similarly yields contradictory reactions. Research shows significance in relative positioning of the police eg. on foot or in a vehicle. Not only were there differences in levels of fear but a positive influence could be turned negative as result of perceived power imbalance between police and citizens (Salmi, Gronroos, \& Keskinen, 2004).

Moreover, strong gender specific influence returned to the topic during early 2000's. Gender based studies led the topic under scrutiny by sociologists, victimologists, psychologists, planners, and geographers establishing gender based differences in fear levels (Day, 1994; Fisher \& Nasar, 1993; Fisher \& Sloan, 2003; Klodawsky \& Lundy, 1994; Lane \& Meeker, 2003; May, 200 I; May \& Dunaway, 2000; May, Vartanian, \& Viro, 2002; Reid \& Konrad, 2004; Schafer et al., 2006; Smith \& Torstensson, 1997; Wallace \& May, 2005). Male specific considerations were explored to understand men's experiences such as fear of the unknown, fear of confrontation, and safety in numbers (Fisher \& May, 2009). The gender studies coincided with renewed attention to CPTED strategies (R. Atlas, I.; \& Saville, 20I3) suggesting various prescriptive measures had forgotten Jacobs (196I) and Wood's (196I) originating concepts, also coloured by gender considerations. Reactions to the prescriptive approach of first generation CPTED mounted elevating the importance of community. At the essence of this is the idea of inclusion and belonging, opposing earlier prescriptive strategies (R. Atlas, I.; \& Saville, 20I3). Community also includes the 'offender', and belonging denotes deep rooting in place, making any approach necessarily place specific rather than a customisable template. This inclusive and thereby safe community approach base on people caring about their environment and the people within it. Examples include Barrier Free Space designs of Wohnstrasse, encounter zones, and Pedestrian Priority Zones (PPZ) which eliminates physical safety structures such as street

78 | The Journal of Public Space, 3(I), 20I8 | ISSN 2206-9658

City Space Architecture / Queensland University of Technology / UN-Habitat 
curbs and fencing in order to re-awaken the user's survival instinct. Early findings from research on such alternate designs confirm they improve safety (Schweizer \& Fasciati, 2008).

Second generation CPTED acknowledges human cognitive mapping which individuals use for managing spatial and temporal information about the physical and social nature of their environment. Such maps guide behavioural decisions and give individuals "a selective advantage in a difficult and dangerous world that is necessary for survival" (Kitchin, 1994, p. 2). Understanding these maps and the sequence of cues which forms them, show far greater potential in providing understanding of the fear-crime relationship than simply measuring levels of fear (Merry, 198I): Merry also note the reoccurrence of interaction as significant. Interacting, even simply venturing into a place immediately heed "criminalizability" of space (Van der Wurff, van Staalduinen, \& Stringer, 1989, p. 145). Inhabitation of space is hence perceived to decriminalise it. The action of inhabiting relates to our individual need to recreate and express our identity, plotting out of space our corner of the world (Bachelard, 1964, 1969; Cooper-Marcus, 1995). Danger is perceived when venturing outside this mapped sphere, the territory of our identity, acutely awakening our mapping ability as the accuracy of our cognitive map becomes pivotal to our safety in unfamiliar environments (O'Brien \& Wilson, 20II). The essence of feeling safe lies in control over territory. Within 'our territory' the cues are familiar and rules clear. It is, in accordance with the statistics of crime versus perceived dangerous areas, along the edges - within the uncontrolled - that crime is most prevalent (Brantingham \& Brantingham, 1995). Yet, our societal trends are increasingly nomadic with strong drives to explore new and unknown places. This need is noted by Cooper-Marcus (1995) as a necessary act of defiance in a child's development of her/his identity. Bestrom (2009, p. 199) describes travel as "a unique opportunity for selfexploration" which by removal from our familiar surroundings provides the opportunity to "new philosophical ideas and develop new ways of seeing the world." Such increasingly nomadic patterns further changes known dynamics as our identity is a result of our context more so than our context is a representation of our identity (Pallasmaa, 1994). As we up-root from traditionally inhabited place, we lose the foothold of our identity. However, after the $9 / 1 /$ tragedy and subsequent national security threats around the world, significant changes have occurred. Most noticeably, the omnipresent surveillance and increased displays of authority, particularly at high-risk entry and exit nodes (R. I. Atlas, 20I3). This has notably affected the sense of freedom of travel. The threat to our 'home' on an international scale clearly provokes the feelings of exposure and danger with which this research is concerned. It would appear from the literature examined that threat to our home and identity, our very being in this world, is essential for awakening our environmental awareness and sense of individual responsibility for our own and our community's safety.

Whilst literature on the topic is extensive, there is little consideration given to safety inherent in uncontrolled but inclusive communities, communities which include both 'victim' and 'offender'. Inclusive communities empower individuals, provoke them to safeguard themselves, and allow them to inhabit the environment. An exclusive community weakens both included and excluded creating instead a need for authoritarian guardianship. Whilst both are viable solutions, the exclusive community inevitably leave residual space outside its border. Its exclusivity becomes the generator of the 'edgecondition' favourable of crime. Including our fears into our everyday lives, allows us to 
inhabit the same space as our perceived 'offender'. Not only lessening fear itself but providing opportunity to understand the offenders internal environment, just as Jeffery (197I) initially called for.

\section{Methodology}

The purpose of this research is to examine how public spaces can evoke a sense of danger through provision of simple features. As the study inquiries the phenomenon of danger, the theoretical structure of "knowledge of essences" (Husserl, 20I2, p. 3) was a logical selection. Phenomenology aims for understanding the un-biased nature of being, with additional input as variables of the experiential whole. Hence phenomenology asks for a wide-gazing and abductive methodological approach. Phenomenology is suited to exploring the sensation created by being in danger as it identifies the essential sensation and by doing so also identify elements affecting the resultant experience. Using a phenomenological framework to uncover data will not only identify particularities in the environment affecting the essence of danger sensing, but also suggest categories of particularities grouped together indicative of trends imposed on the subjects by the urban environment.

\section{Research method}

Research was conducted in six stages as illustrated in figure I. The process was separated into two phases, one aimed at understanding the danger phenomenon, the other at exploring human reasoning and reaction to the phenomenon. Phase one included reviewing existing knowledge, and two pilot studies. Phase two contained a survey, analysis of survey responses and finally resulting in theory development.

Main data were collected via an online survey comparing responses to questions related to three urban environments, pictured as exemplary of three types of urban scenarios which can be found in most cities today. The three sceneries are I) Sanitized 2) Surveillanced and 3) Uninhibited environments.

Participation was voluntary. All participants were over 18 years of age.

Participation involved completing the 30 item anonymous survey with closed and open as well as likert scale answers taking approximately $10-15$ minutes of participant's time. Questions included; How connected do you feel to others in this situation? Do you feel exposed or sheltered in this environment? and Do you think people care about this place?

Pilot study I was an experiment in using Pinterest as a tool for interdisciplinary unstructured research into the general topic of safety after dark. The research team created a Pinterest board that was used for collecting virtual images related to the topic of safety after dark, through a search of related keywords. The collected images on the board were then thematically analysed by grouping into emerging themes. Resulting in a number of thematic concepts related to safety after dark.

Pilot study 2 implemented the knowledge gained in previous steps, applying it to testing during a public event in Brisbane, Australia (URBNE festival - 28/30 March 20I4). The image content used the experimental technology of 'Local Commons', a smart phone application allowing public interaction with image content. The aim of the pilot was to gauge the public reaction to the "Safety After Dark" topic. A finding of the pilot was related to familiarity of place as mitigating of level of danger experienced.

80 | The Journal of Public Space, 3(I), 20I8 | ISSN 2206-9658

City Space Architecture / Queensland University of Technology / UN-Habitat 


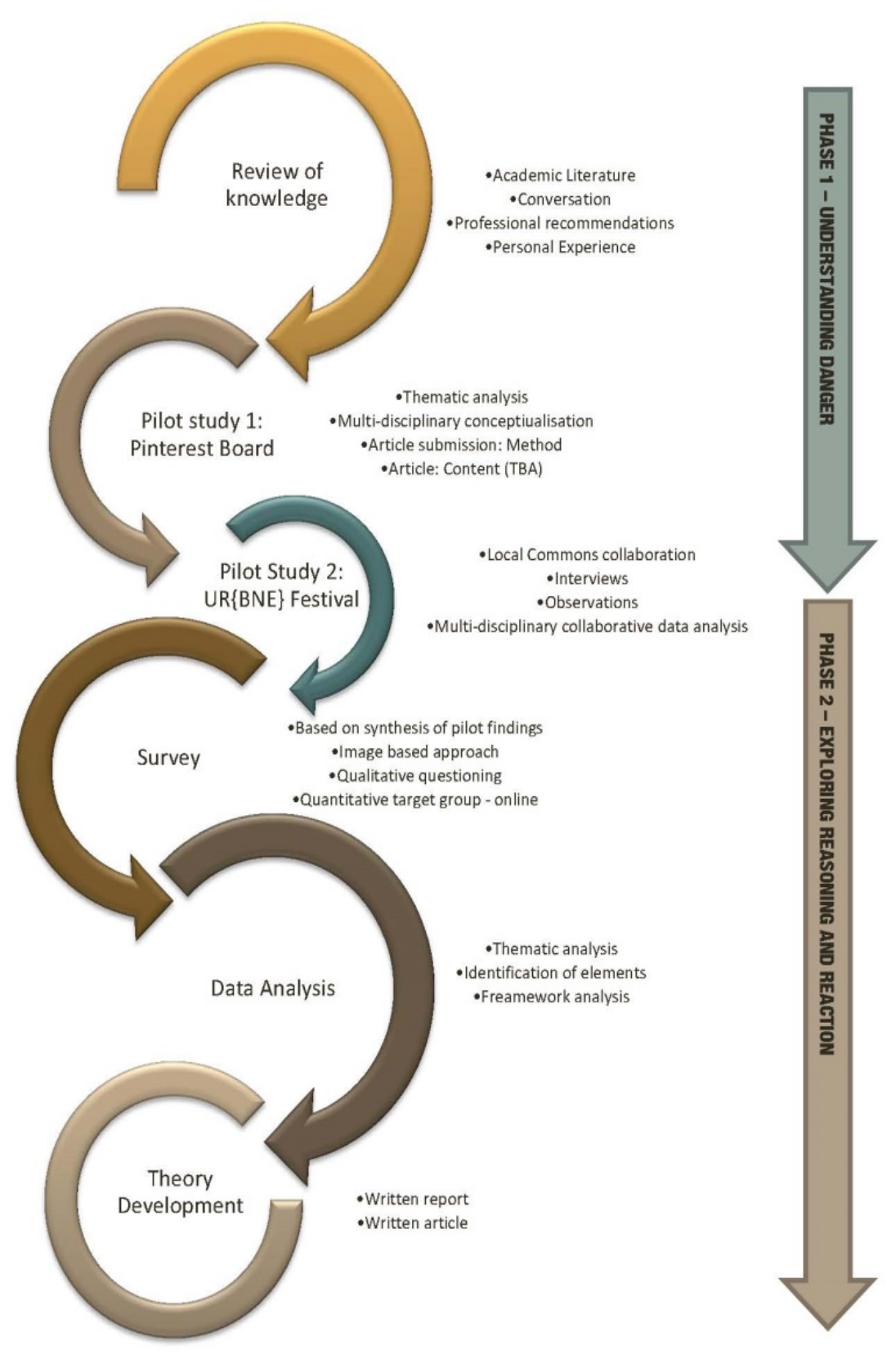

Fig. I. Research Structure.

The pilots assist the development of a framework to guides the manipulation of images fundamental to the survey. Using images within the survey allows rapid-response questioning techniques aim at drawing on the subjects subconscious rather than rational responses, whilst in the form of a quantitative collection technique.

The final three steps aim to explore the reasoning and reaction to danger sensing. The survey contained images of the urban landscape, staging scenarios of varied nature. Three image-scenes where manipulated: 'Authoritarian' (figure 2), 'Sterilized' (figure 3), and 
'Uncontrolled' (figure 4) and a set of ten questions were asked for each image. Authoritarian scenery was neat, clean, and displayed powerful signage and remotely controlled security devices. Sterilized settings lack distinctive identity but have good visibility, and vertically framing elements. Uncontrolled settings were unlawfully decorated, lacking vertically framing elements, with lowered level of artificial lighting.

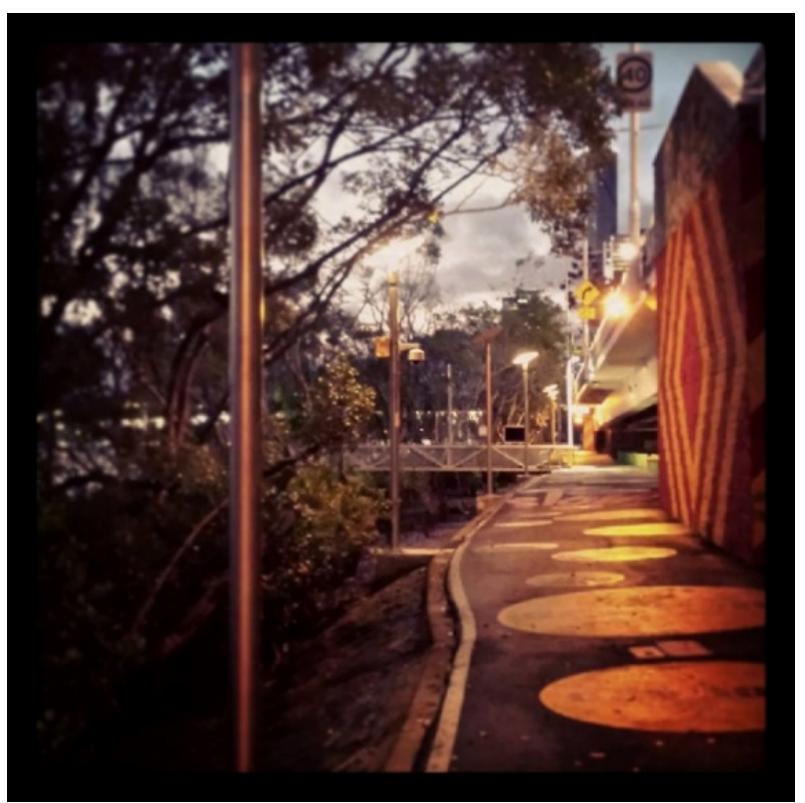

Fig. 2. Scenario A “Authoritarian”.

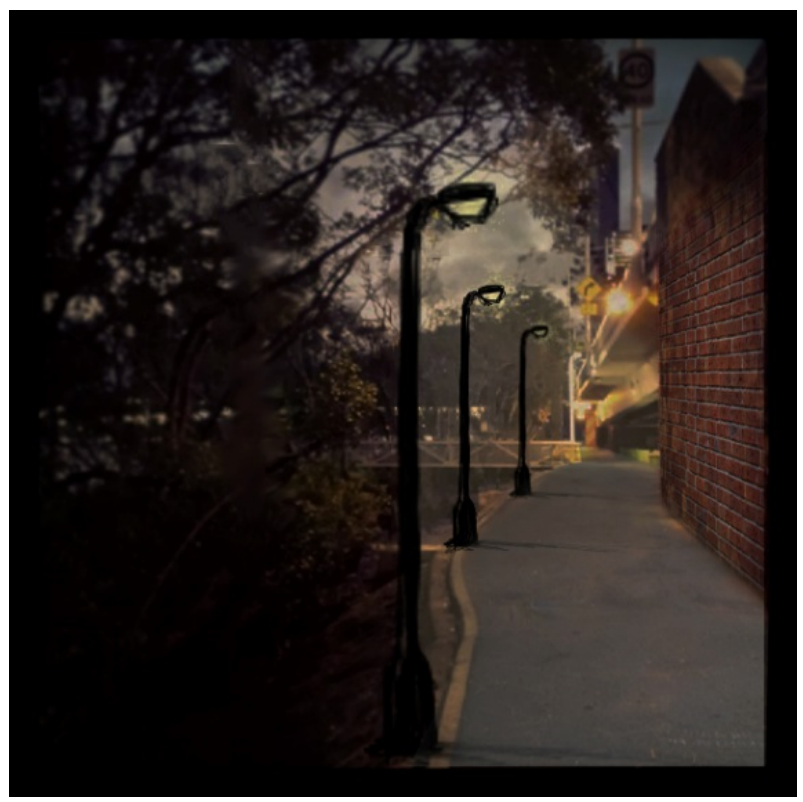

Fig. 3. Scenario B "Sterilised”. 


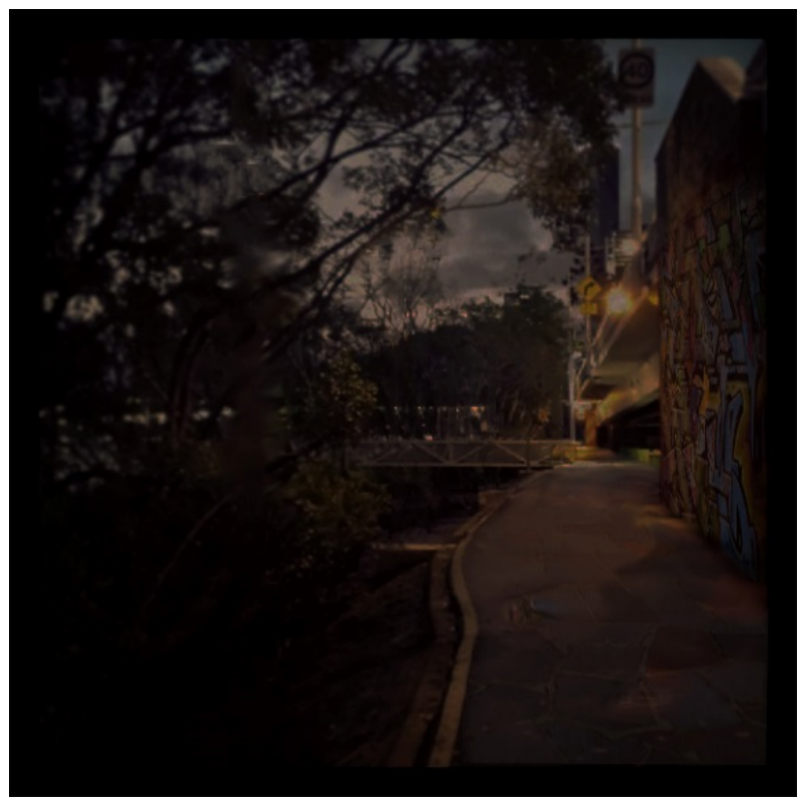

Fig. 4. Scenario C "Uncontrolled".

A set of ten questions followed each image. Eight of the questions provided tick-a-box response options, two required open-ended answers. Questions were as follows:

I. Is this a safe or an unsafe place?

2. How connected do you feel to other people in this situation?

3. Do you feel exposed or sheltered in this situation?

4. Do you think people care about this place?

5. Is this a familiar environment to you?

6. If you were threatened when in this environment, what would you do to protect or defend yourself?

7. If you were planning to go to this place, would you bring anything in particular as a safety measure?

8. If you were planning to go to this place, would you take any precautions before you left?

- What do you think this place is used for?

- What is this place? If you were to give it a name, what would it be?

The survey was distributed over the social media platform of Facebook and via direct email.

Analysis of survey data expected to strengthen or weaken themes of the analytical framework, or generate additional themes. Details recorded as significant by participants of the survey was coded and added into the framework under the existing themes.

\section{Limitations}

Data collection was local to Brisbane, Australia, although the survey was distributed online with potential global reach of self-selecting participants. Survey images, however, were created from local photos, and their cultural and contextual nature limit responses. 
Survey distribution online limited respondents to those with computer access as well as present on social media. As the study does not attempt to investigate the nature of danger relative to age, study was limited by the exclusion of anyone below 18 years.

\section{Findings}

Survey generated 44 completed submissions over a three-week-period in May 20I4. The two open-ended questions contained in the survey are not shown in graph format and not included in the overall response diagram.

Scenario A: "Authoritarian"

Scenario A exemplifies a high level of remotely controlled safety measures such as surveillance cameras, graphical warnings and ominous lighting fixtures. Significantly, across all questions, many respondents felt "exposed" (Q3a), and their choice of safety measure was the mobile phone.

Most felt the scenario pictured in Scenario A was unsafe with a combined $49 \%$ answering either of the "unsafe" options as opposed to $37 \%$ answering one of the two "safe" options.

In relation to connectivity and sense of presence, $44 \%$ felt others presence out of sight, making them nervous, and $7 \%$ replied that the sense of presence they cannot see did not concern them.

Significantly, responses to which scenario made respondents feel exposed or sheltered saw $78 \%$ responding that scenario A made them feel exposed. While $44 \%$ replied they believe somebody cares about this place, this caring is only of the space being functional. The majority of respondents $(41 \%+2 \%)$ knew the place pictured, but rarely or never used it. Only $9 \%$ knew of and frequently used the place.

Most respondents would attempt to run away if they encountered a dangerous situation while within this space. No respondents $(0 \%)$ would attempt to hide.

When asked what conscious precautions would be taken when planning to travel through the space 34\% replied "nothing in particular" with an even distribution between the other three suggestions. The most popular precautionary object to bring was the mobile phone with a response rate of $61 \%$.

\section{Scenario B: Sterilised}

Scenario B exemplifies neat and clean, a "sterilised" place with traditional street lighting. As with Scenario A, Scenario B is perceived a situation of exposure with (50\%) assessing the situation as unsafe to varying degree. Regarding presence and connectedness within the space, most respondents $(32 \%+20 \%)$ felt a lack of presence, and $44 \%$ responded that they sensed "somebody is nearby".

The majority (78\%) felt exposed by the situation. In relation to perceptions of care of place, $70 \%$ responded affirmatively, while $39 \%$ thought care for the place was purely functional. The majority of respondents $(44 \%)$ did not know this place; few $(7 \%)$ recognised and rarely use it. Only $5 \%$ knew of and frequently used the place.

As in Scenario A, respondents again showed strong preference for running away from a perceived threat and no respondents saw the scene favourable for hiding.

When asked what precautions would be taken before going to this place, respondents showed no strong preference for either option provided and $30 \%$ replied they would do

84 | The Journal of Public Space, 3(I), 20I8 | ISSN 2206-9658

City Space Architecture / Queensland University of Technology / UN-Habitat 
"Nothing in particular". Mobile phone was reported as the most favourable object to ensure one's own safety.

\section{Scenario $C$}

Scenario $C$ exemplifies a distinctively un-controlled setting displaying graffiti, low lighting levels and lacking fencing of the path. A main finding was a distinct sense of exposure. Increase was noted in respondents deeming the setting unsafe $(55 \%)$ and no respondents found the setting to be safe. "Nobody is here! I feel lost and scared" combined with the option suggesting abandonment of activity comprise $63 \%$ of the responses. Respondents $(80 \%)$ recorded feeling exposed in this scenario. A combined $55 \%$ felt nobody cared about the space. Respondents who knew the place and those who did not were balanced. Respondents majorly chose the "Run away" option as self-defence, but in this scenario hiding also emerges as being an option.

While the mobile phone is still the most preferred object of defence, this scenario significantly recorded respondents choosing the 'weapon' option, lesser rate on the "Nothing in particular" option is also noticed.

\section{Discussion}

Following sections analyse and discuss findings provided by the survey data, highlighting key findings and emphasising important aspects of the study. It further seeks to explore possible explanations for the findings comparing and contrasting them to results of other relevant studies in order to contextualise the results. Finally, implications of findings for future research are discussed.

Safe or unsafe?

It was clear that Scenario $C$ was perceived as considerably unsafe, whereas Scenarios A and $B$ were more moderately or even judged as somewhat safe. This confirms the findings of earlier research (Atkins, 199I), suggesting that there is a correlation between provision of lighting and perceived safety albeit not necessarily indicative of actual safety (Kirk, 1988; Stamps, 2005).

Scenario A was convincing of a presence, this evokes feelings of discomfort. In contrast the ungoverned scene in Scenario $C$ signal to respondents the space being abandoned, making them feel lost and scared.

Evenly distributed between the three Scenarios a majority felt exposed in all three situations. Interestingly, this indicates that features such as lighting levels, physical obstructions and/or potential hiding spaces do not significantly affect the sense of exposure experienced.

Do people care about this place?

Significant differences were noticed between Scenario A and B as compared to Scenario $\mathrm{C}$ in terms of the perceived care given to the space. Responses indicates poor or lacking lighting, as previously suggested (Kirk, 1988; Stamps, 2005) heightening fear despite generally having low crime levels (Brantingham \& Brantingham, 1995). No significant difference in response rates between the two scenes with differing types of lighting was recorded, supporting the claims of Marchant (2004) that increases in lighting does not increase safety. 
Finding indicates that graffiti affects our perception of place. Whilst being characteristic indicators of territoriality (Ley \& Cybriwsky, 1974; Skogan, 1988) it is perceived as someone caring for place. A clear distinction in perception of graffiti and authoritarian signage was also noted.

What is this place is used for?

When asked about the use, the first two scenarios again proved similar, with Scenario $C$ distinguishing itself, examples of answers to this question are found in table 3. However, a slight variation is noted in responses to the first two images. In Scenario A, there was little doubt the space was for transitioning through, this is not a space for meandering. Similarly most responses observe a space for movement in Scenario B, although it seems the pace has slowed down and words like "wander" are used and respondents begin considering uses of the space other than the passing through.

A slowing pace and increased sensory awareness of place becomes obvious in Scenario C where respondents even imagine the history, difference in day and night usage, human presence, and generally begin to give detailed and more imaginative responses to what this place may 'be'. It would seem as though lesser lighting levels, and removal of security signage and surveillance awaken our imagination and in several respondents a interest of place which was not present in the previous two scenarios. Nevertheless the uses imagined remain less accepted forms of community life.

Is this a familiar environment to you?

Familiarity of place decreased significantly in Scenario $C$ as did frequency of use. With primary alterations to this option being lighting level, graffiti, and enclosing man-made structures, it is noted that the combination of cues has significant effect on familiarity. Possible explanations for this may be disorientation experienced with diminished eyesight, and reliance on sight-sense in way-finding. Other explanations are also possible in terms of sense of security gained from directional and enclosing features of the built environment and the sense of authoritarian governing of space. This finding would benefit from further exploration to investigate the causes and relationships beyond the scope of this study.

What would you do to protect or defend yourself?

Reactions to potential threat were similar in all three scenarios, the majority choosing to "run away" from the situation. This indicates flight instinct being a common response to exposure, and correlation of these two components a purposeful further investigation. The second preference was to pick up a weapon, i.e. fighting instinct, with respondents more prone to 'fight' in Scenario C. Despite respondents perceiving human presence in Scenario A, this did not show as an increased tendency to call out for help. This finding suggests directional understanding of the environment being of higher importance than alerts and warning of where to be wary of danger, as the former would allow mental mapping of potential flight routes.

Would you bring anything in particular as a safety measure? The mobile phone was noted as a personal safety measure by most respondents. In two of the three scenarios, a mobile phone was a preferred safety device to a weapon. This not only indicates that carrying a weapon does not need to heighten ones sense of

86 | The Journal of Public Space, 3(I), 20I8 | ISSN 2206-9658

City Space Architecture / Queensland University of Technology / UN-Habitat 
security, but also that carrying a mobile phone, although having little physical ability to protect a person, can alter perception safety. Further investigation about attributes of mobile phones that promotes this sense of security would be valuable.

Would you take any precautions before you left?

Aa distinct unwillingness among participants to take conscious precautions before venturing out into a potentially dangerous place was noted. However, a distinct increase in consideration of not going alone into Scenario $C$ is consistent with the previous finding of this scene being more unsafe than the previous two. This shows that the cues contained within Scenario $C$ are conducive to heightening environmental awareness and a need to ensure one's own safety.

If you were to give this place a name?

When asked to name the place, Scenario A provoked names containing words such as Caution, Isolation, River, Warning, and Ugly.

Scenario B has a calmer impression, with respondents using words such as Serenity, Romantic, and Quiet. While responses make clear that it is a scary and dangerous place, names such as Quiet city walk and Evening Grove have a significantly more poetic tone to them than eg. 'Urban Shortcut'

Scenario $C$ is consistently named relating to the place's abandonment/desertedness. The graffiti is mentioned as Art by one respondent. Interestingly one respondent manages to make a very clear comment relating to the interest of this study saying "Looks like an abandoned alley, Walk at Your Own Risk". This acknowledges abandonment, or the sense of lacking authoritarian governance here, as alerting individuals to enter this space in an attentive state of mind. Moreover, Scenario $C$ is the only image to exhibit a response which contains the word 'love'. While this response is noting a lack of love, it is yet significant that the word is at all connected with the context. Findings for this question are summarised in table 2.

How does the responses compare?

Combining responses to the three scenarios, it is evident that Scenario $C$ has the greatest differentiation from the previous two. Scenario $C$ is deemed I) significantly less safe 2) increasingly exposing 3) significantly less familiar and 4) significantly more likely to heighten conscious self-protective preventative actions.

The main difference between Scenarios $A$ and $B$, and Scenario $C$ is the governance factor; who is governing the space, and what level of self-governance is expected by a person entering the space. Scenarios A and B are clearly open public spaces, governed by an authority (council or similar). In these spaces the users are expected to follow commonly understood rules which apply to everyone and the governing power would likely be some form of security e.g. police. However, in Scenario $C$ it is not obvious if the space is public, who is governing it, or what rules are expected to be followed or how or if these rules would be maintained. This finding confirms the success of the 'Encounter Zones' tested in Europe, suggesting it would be useful knowledge to understand more about what environmental cues relate, and how, to governance which in turn either promote or demote individuals' sense of urgency to ensure their own safety. 


\section{Conclusions}

This study explored the relationship between perception of public space and safety within them, particularly focusing on the relationship between imposed safety measures and its effect individual responsibility and environmental awareness. It did so by examining what our reaction is to cues of danger in the environment. A significant finding of this exploratory study is that the exact same public space, with the actual same environment in terms of safety, is perceived in different ways when different control measures are present. A well-lit highly visible and camera surveyed public space is perceived as much safer than one where there is no clear presence of authoritarian control. Users feels equally exposed in lit as in unlit spaces, as do they in a highly surveyed or in an 'abandoned' space. While surveillance and lighting seemed to create a perception that there were others nearby, calling out for help if experiencing a danger situation was rarely suggested as an option. Familiarity is significantly affected by lighting levels, graffiti, and enclosing structures in combination. Enclosing structure, such as rows of street lamps and/or solid walls, had positive impact on how familiar a place was whereas graffiti and lack of lighting saw familiarity and recognition diminish and more likely to promote conscious self-protective preventative actions among respondents. The analysis suggests that the perceived presence of governing forces in the space impacts on behaviour and confirms the notion of the order of chaos on which design concepts such as 'Encounter Zones' build.

Understanding danger and how this condition human behaviour can be a useful tool to designers dealing with public space. The extreme mitigation of risk has so far resulted in highly designed and regulated spaces, but an alternative approach to safety and risk mitigation has already been explored in the so called 'naked streetscape' (Moylan, 2005). The removal of barriers and deterrents has increased the sense of vulnerability in users, mainly divers, within major European public spaces, for example Kensington High Street. The feeling of uneasiness and perceived risk has resulted in drivers self-regulating their behaviours producing a much safer environment for pedestrians.

Findings from this pilot suggest that the inclusion or not of specific features in our public spaces can affect our self-awareness and our behaviours. How to bring this preliminary finding into the actual design of a public space needs further research and more exploration, but it is suggested as a possible strategy to manage the growing complexity of our cities. With globalisation posing new opportunities and threats alike, urban environments are fast evolving into something new and unknown, as exciting as it may seem dangerous. Learning from the thrill-seeking adventurer's ability to stay safe, and by understanding the workings of the sought after thrill, will allow creation of much safer, but also much more stimulating urban environments. While an extensive body of knowledge already exists on topics of safety and perceived safety in urban environments, this explorative study has focused on unravelling questions awoken by evermore present authoritarian presences in public spaces. The study has highlighted the need of additional research on the power relationship created by safety conscious augmentation of urban environments with the complex nature of today's user base. It is clear that more knowledge of this relationship could improve safety conscious design measures as well as benefit the collective body of knowledge. 
Table I: Selection of Responses to question related to the suggested use of place for Scenario A-C.

\begin{tabular}{|c|c|c|}
\hline SCENARIO A & SCENARIO B & SCENARIO C \\
\hline $\begin{array}{l}\text { Transportation; it is not a } \\
\text { social space. }\end{array}$ & $\begin{array}{l}\text { Transport something, } \\
\text { alleyway. not somewhere to } \\
\text { stay }\end{array}$ & $\begin{array}{l}\text { It's the same place as before } \\
\text { but is even scarier without } \\
\text { proper lighting and signs. }\end{array}$ \\
\hline $\begin{array}{l}\text { Moving through - no one stays } \\
\text { there }\end{array}$ & $\begin{array}{l}\text { To get from one side of the } \\
\text { road to the other }\end{array}$ & $\begin{array}{l}\text { Drug deals are the first thing } \\
\text { that springs to mind. Graffiti, } \\
\text { also, so m maybe it's a gang } \\
\text { hangout. }\end{array}$ \\
\hline Thoroughfare & A walkway to get from a to $b$ & $\begin{array}{l}\text { it is a walkway but the } \\
\text { darkness and graffiti indicate } \\
\text { that its used by people as } \\
\text { something other than that. }\end{array}$ \\
\hline Access and thoroughfare & $\begin{array}{l}\text { Looks safer though, since } \\
\text { there seem to be less } \\
\text { distractions and the light } \\
\text { looks more familiar. The brick } \\
\text { wall also adds some charm. }\end{array}$ & $\begin{array}{l}\text { Graffiti probably was a nice } \\
\text { place once }\end{array}$ \\
\hline Path for Joggers and bicycles & $\begin{array}{l}\text { Smell like a toilet, and play } \\
\text { host to some } 5 \text {-minute stands. }\end{array}$ & $\begin{array}{l}\text { Clearly somebody hangs } \\
\text { around here. }\end{array}$ \\
\hline
\end{tabular}

Table 2: Selection of Responses to question related to the name of place for Scenario A-C.

\begin{tabular}{lll} 
SCENARIO A & SCENARIO B & SCENARIO C \\
\hline Cautious park & Serenity way & Bumpy \\
\hline Isolation & Evening Walk & Art park \\
\hline Spooky Lane & Back alley & $\begin{array}{l}\text { It's an unloved not used much, } \\
\text { it wouldn't have a name }\end{array}$ \\
\hline Ugly Walk & Afterthought & $\begin{array}{l}\text { Waiting for imminent death } \\
\text { lane }\end{array}$ \\
\hline Rivers edge & Quiet city walk & The gutter \\
\hline Ambush Alley & A pathway. Romantic path & Forgotten \\
\hline Lonely lane & Lonesome Alley & No-man's land \\
\hline Cavern of fear & Dead end & Lost lights \\
\hline Urban trails & Lamp post horror & The Forgotten Pathway \\
\hline Urban Shortcut & This actually looks like a quite & Rape alley \\
\hline Underpass Alley & romantic setting & Graffiti city
\end{tabular}




\section{References}

Atkins, S. (199I). The influence of street lighting on crime and fear of crime. London: Home Office.

Atlas, R., I.; \& Saville, G. (20I3). Implementing CPTED 2 I st Century Security and CPTED (PP. 875882): CRC Press.

Atlas, R. I. (2013). Offensible Space 2 I st Century Security and CPTED (PP. I I 9-I46): CRC Press.

Bachelard, G. (1964). The poetics of space. New York: Orion Press.

Bachelard, G. (1969). The poetics of space. Boston, Mass: Beacon Press.

Barnard-Wills, D., Moore, C., \& McKim, J. (20I2). Introduction: Spaces of Terror and Risk. Space and Culture, 15(2), 92-97. doi:I0.1 I77/I20633I2II4300I2

Beck, U. (1999). World risk society. Malden, MA; Cambridge, UK: Polity Press.

Bestrom, E. (2009). Moving Beyond Borders: The Creation of Nomadic Space through Travel. Intersections, IO(I), 199-217.

Brantingham, P., \& Brantingham, P. (1975). Residential Burglary and Urban Form. Urban Studies, 12(3), 273-284.

Brantingham, P., \& Brantingham, P. (198I). Environmental criminology. Beverly Hills: CA: Sage Publications.

Brantingham, P., \& Brantingham, P. (1993). Nodes, paths and edges: Considerations on the complexity of crime and the physical environment. Journal of Environmental Psychology, I3(I), 328.

Brantingham, P., \& Brantingham, P. (1995). Criminality of place. European Journal on Criminal Policy and Research, 3(3), 5-26.

Brantingham, P., Brantingham, P., \& Molumby, T. (1977). Perceptions of Crime in a Dreadful Enclosure. The Ohio Journal of Science, 77(6), 256-26I.

Brownlow, A. (2005). A geography of men's fear. Geoforum, 36(5), 581-592. doi:http://dx.doi.org/10.1016/j.geoforum.2004.1 I.005

Burgess, E. W. (1916). Juvenile Delinquency in a Small City. Journal of the American Institute of Criminal Law and Criminology, 6(5), 724-728. doi:10.2307/II 33346

Chitrakar, R. M., Baker, D. C., \& Guaralda, M. (2017). Emerging challenges in the management of contemporary public spaces in urban neighbourhoods. ArchNet-IJAR, I I(I), 29-43.

Cooper-Marcus, C. (1995). House as a mirror of self: exploring the deeper meaning of home. Berkeley, Calif: Conari Press.

Cordner, G. W. (1986). Fear of crime and the police: an evaluation of a fear-reduction strategy. Journal of police science and administration, I4(3), 223.

Cox, C. J., \& Guaralda, M. (2016). Public space for street-scape theatrics. Guerrilla spatial tactics and methods of urban hacking in Brisbane, Australia. The Journal of Public Space, I(I), II3-128. doi:I0.5204/jps.vlil.I4

Crowe, T. D., \& National Crime Prevention Institute. (1991). Crime prevention through environmental design: applications of architectural design and space management concepts. Boston: Butterworth-Heinemann.

Dangschat, J. S. (2009). Space matters - Marginalization and its places. International Journal of Urban and Regional Research, 33(3), 835-840. doi:I 0.I I I I/j. I 468-2427.2009.00924.x

Day, K. (1994). Conceptualizing Women's Fear of Sexual Assault on Campus: A Review of Causes and Recommendations for Change. Environment and Behavior, 26(6), 742-765.

Despard, E. (20/2). Cultivating Security: Plants in the Urban Landscape. Space and Culture, 15(2), 15I-163. doi:10.1177/120633/21/430019

Fattah, E. A. (199I). Understanding criminal victimization: an introduction to theoretical victimology. Scarborough, Ont: Prentice-Hall Canada.

Ferri, E. (1896). Criminal sociology. New York: D. Appleton and company.

Fisher, B., \& May, D. (2009). College Students' Crime-Related Fears on Campus: Are FearProvoking Cues Gendered? Journal of Contemporary Criminal Justice, 25(3), 300-32I. doi: I0.1 I77//0439862093350I3

90 | The Journal of Public Space, 3(I), 20I8 | ISSN 2206-9658

City Space Architecture / Queensland University of Technology / UN-Habitat 
Fisher, B., \& Nasar, J. (1992). Fear of Crime in Relation to Three Exterior Site Features: Prospect, Refuge, and Escape. Environment and Behavior, 24(I), 35-65.

Fisher, B., \& Nasar, J. (1993). 'Hot spots' of fear and crime: A multi-method investigation. Journal of Environmental Psychology, 13(3), 187-206.

Fisher, B., \& Sloan, J. (2003). Unraveling the fear of victimization among college women: Is the "shadow of sexual assault hypothesis" supported?*. Justice Quarterly : JQ, 20(3), 633-659.

Foth, M. (20II). From social butterfly to engaged citizen: urban informatics, social media, ubiquitous computing, and mobile technology to support citizen engagement. Cambridge, Mass: MIT Press.

Herzog, T. R., \& Chernick, K. K. (2000). TRANQUILITY AND DANGER IN URBAN AND NATURAL SETTINGS. Journal of Environmental Psychology, 20(I), 29-39. doi:http://dx.doi.org/I0.1006/jevp.1999.0I5 I

Herzog, T. R., \& Miller, E. J. (1998). The Role of Mystery in Perceived Danger and Environmental Preference. Environment and Behavior, 30(4), 429-449. doi:10.1 177/00139165980300040 I

Husserl, E. (20I2). Ideas : General Introduction to Pure Phenomenology

Jacobs, J. (Ed.) (1961). The death and life of great American cities. New York: Vintage Books.

Jeffery, R. (197I). Crime prevention through environmental design. Beverly Hills, Calif: Sage Publications.

Kirk, K. L. (1988). Factors affecting perceptions of safety in a campus environment. Environmental Design Research Association, 3, 215-221.

Kitchin, R. M. (1994). Cognitive maps: What are they and why study them? Journal of Environmental Psychology, I4(I), I-19. doi:http://dx.doi.org/10.1016/S0272-4944(05)80194-X

Klodawsky, F., \& Lundy, C. (1994). Women's safety in the university environment. Journal of Architectural and Planning, II, I28-33I.

Kuo, F. E., Bacaicoa, M., \& Sullivan, W. C. (1998). Transforming Inner-City Landscapes: Trees, Sense of Safety, and Preference. Environment and Behavior, 30(I), 28-59. doi:10.1177/0013916598301002

Lane, J., \& Meeker, J. (2003). Women's and men's fear of gang crimes: Sexual and nonsexual assault as perceptually contemporaneous offenses*. Justice Quarterly : JQ, 20(2), 337-37I.

Ley, D., \& Cybriwsky, R. (1974). Urban Graffiti as Territorial Markers. Annals of the Association of American Geographers, 64(4), 49I-505.

Loewen, L. J., Steel, G. D., \& Suedfeld, P. (1993). Perceived safety from crime in the urban environment. Journal of Environmental Psychology, I3(4), 323-33I. doi:http://dx.doi.org// 0.1016/S0272-4944(05)80254-3

Marchant, P. (2004). A Demonstration That the Claim That Brighter Lighting Reduces Crime Is Unfounded. British Journal of Criminology, 44(3), 44I-447.

May, D. (200I). Adolescent Fear of Crime, Perceptions of Risk, and Defensive Behaviors: An Alternative Explanation of Violent Delinquency. Lewiston, NY: Edwin Mellen Press.

May, D., \& Dunaway, R. (2000). Predictors of adolescent fear of crime. Sociaological Spectrum, 20, 149-168.

May, D., Vartanian, L., \& Viro, K. (2002). The impact of parental attachment and supervision on fear of crime among adolescent males. Adolescence, 37(267-287).

Merry, S. E. (198I). Urban danger : life in a neighborhood of strangers. Philadelphia: Temple U.P.

Moylan, D. (2005). Kensington High Street: Making it Happen. Paper presented at the Walk2 I-VI "Everyday Walking Culture", The 6th International Conference on Walking in the 2Ist Century, Zurich, Switzerland.

Newman, O. (1972). Defensible space; crime prevention through urban design. New York: Macmillan.

Pain, R. H. (1997). Social Geographies of Women's Fear of Crime. Transactions of the Institute of British Geographers, 22(2), 23।-244. doi: I0.2307/6223। I

Pallasmaa, J. (1994). Identity, Intimacy and Domicile. Notes on the phenomenology of home. Finnish Architectural Review, I. 
Ramsay, M., \& Newton, R. (199|). The effect of better street lighting on crime and fear : a review. London: Home Office, Crime Prevention Unit.

Reid, L. W., \& Konrad, M. (2004). The gender gap in fear: Assessing the interactive effects of gender and perceived risk on fear of crime. Sociological Spectrum, 24, 399-425.

Robinson, M. B. (1996). The theoretical development of 'CPTED': 25 years of responses to C. Ray Jeffery. In W. S. L. Freda Adler (Ed.), The Criminology of Criminal Law. New Brunswick, New Jersey: Transaction Publishers.

Salmi, S., Gronroos, M., \& Keskinen, E. (2004). The role of police visibiliy in fear of crime Finland. Policing, 27(4), 573-59I.

Saraiva, M., \& Pinho, P. (20II). A comprehensive and accessible approach to crime prevention in the planning and design of public spaces. Urban Design International, 16(3), 213-226. doi:I0.1057/udi.20II.7

Schafer, J. A., Huebner, B. M., \& Bynum, T. S. (2006). Fear of crime and criminal victimization: Gender-based contrasts. Journal of Criminal Justice, 34(3), 285-30I. doi:http://dx.doi.org/10.1016/j.jcrimjus.2006.03.003

Schweizer, T., \& Fasciati, J. (2008). Accident in meeting areas: Comparison of the situation before and after in Burgdorf, Biel, Lyss and Einsiedeln. 9.

Shaw, C. R., \& McKay, H. D. (1942). Juvenile delinquency and urban areas : a study of rates of delinquents in relation to differential characteristics of local communities in American cities. Chicago: Univ. of Chicago Press.

Skogan, W. G. (1988). Community Organizations and Crime. Crime and Justice, 10, 39-78. doi: $10.2307 / 1 \mid 47402$

Skogan, W. G. (1990). Disorder and decline : crime and the spiral of decay in American neighborhoods. New York: Free Press .

Smith, W. R., \& Torstensson, M. (1997). Gender Differences in Risk Perception and Neutralizing Fear of Crime : Toward Resolving the Paradoxes. British Journal of Criminology, 37(4), 608-634.

Sorensen, S., Hayes, J., \& Atlas, R. (20I3). Understanding CPTED and Situational Crime Prevention 2 Ist Century Security and CPTED (PP. 59-90): CRC Press.

Stamps, A. E. (2005). Enclosure and Safety in Urbanscapes. Environment and Behavior, 37(1), 102I33. doi:10.1177/0013916504266806

Van der Wurff, A., van Staalduinen, L., \& Stringer, P. (1989). Fear of crime in residential environments: testing a social psychological model. Journal of Social Psychology, I29(2), |4|-160.

Wallace, L., \& May, D. (2005). The impact of relationship with parents and commitment to schoolon adolescent fear of crime at school. Adolescence, 40, 458-474.

Warr, M. (1990). Dangerous Situations: Social Context and Fear of Victimization. Social Forces, 68(3), 89I-907. doi:10.2307/2579359

Wilson, J. Q., \& Kelling, G. L. (1982). Broken windows: The police and neighborhood safety. Broken Windows: The Police and Neighborhood Safety.

Winkel, F. W. (1986). Reducing Fear Of Crime Through Police Visibility: A Field Experiment. Criminal Justice Policy Review, I (4), 38I-398. doi: I0.I I 77/088740348600 I00402

Wood, E., Citizens Housing, \& Planning Council. (196I). Housing design: a social theory: Citizens' Housing and Planning Council of New York.

Wood, E., \& United Nations. Dept. of Economic Social Affairs. (1967). Social Aspects of Housing and Urban Development: UN. 